\title{
RADIO EGHO SOUNDING ON A VALLEY GLACIER IN EAST GREENLAND
}

\author{
By J. L. Davis, \\ (Scott Polar Research Institute, Cambridge, England) \\ J. S. Halliday \\ (St. John's College, Cambridge, England) \\ and $\mathrm{K}$. J. Miller \\ (Trinity College, Cambridge, England)
}

\begin{abstract}
Although radio echo sounding equipment has been used with success for measuring the thickness of ice sheets in the Arctic and Antarctic, a valley glacier poses the additional problems of echoes from the valley walls, which may obscure the bottom echoes, and a high attenuation of radio waves in the ice. During July and August 1970, a study was carried out on Roslin Gletscher in Stauning Alper, East Greenland, to investigate the problems of radio echo sounding on a valley glacier. Results show that reflections from the valley walls are minimized by using sufficiently directional antennae, but attenuation of the signal in the ice is higher than that in polar ice at the same temperature. Water in and on the ice probably accounts for much of the attenuation, and the use of a lower frequency or measurements before the melt commences should give improved performance.
\end{abstract}

RÉsumÉ. Sondage par radio-echo dans une vallée du Groenland Oriental. Bien que le matériel de sondage par écho radio ait été utilisé avec succès pour mesurer l'épaisseur des calottes de glace dans l'Arctique et dans l'Antarctique, un glacier de vallée pose le problème supplémentaire des échos par les parois de la vallée qui peuvent brouiller les échos du fond, ainsi qu'une forte atténuation des ondes radio par le glace. Pendant les mois de juillet et d'août 1970, une étude fut conduite sur le Roslin Gletscher dans les Stauning Alper, Groenland Oriental, pour creuser le problème des sondages par écho radio dans un glacier de vallée. Les résultats montrent que les réflexions par les parois de la vallée sont atténuées par l'usage d'antennes suffisamment directionelles, mais l'atténuation du signal par la glace est plus forte que celle obtenue dans la glace polaire à la même température. L'eau dans et sur la glace intervient probablement pour la plus grande part dans cette atténuation; l'usage d'une fréquence plus basse ou la pratique des mesures avant le début de la fusion devraient améliorer la performance.

Zusammenfassung. Radar-Echolotung auf einem Talgletscher in Ostgrönland. Radar-Echolotgeräte wurden zwar erfolgreich zur Bestimmung der Mächtigkeit von Eisschilden in der Arktis und Antarktis verwendet. Bei einem Talgletscher treten jedoch die zusätzlichen Probleme der Echos von den Talwänden, die sich den Bodenechos überlagern können, und der starken Abschwächung der Radiowellen im Eis auf. Während des Juli und August 1970 wurde eine Untersuchung auf dem Roslin Gletscher in den Stauning Alper, Ostgrönland, durchgeführt, um die Probleme der Radar-Echolotung auf einem Talgletscher zu studieren. Die Ergebnisse zeigen, dass die Reflexionen von den Talwänden bei Benutzung einer hinreichend ausgerichteten Antenne vermindert werden, dass aber die Abschwächung der Signale im Eis höher ist als für Polareis derselben Temperatur erwartet. Wasser in und auf dem Eis verursacht wahrscheinlich den grössten Teil der Abschwächung; die Verwendung niedrigerer Frequenzen oder Messungen vor Beginn der Schmelze sollten bessere Resultate liefern.

\section{INTRODUCTION}

During July and August 1970, a Cambridge expedition carried out a programme of glaciological measurements and surveying on Roslin Gletscher (Fig. I) in Stauning Alper, East Greenland.* The primary investigation was to determine the glacier ice thickness by means of radio echo sounding. Most radio echo sounding work to date has been carried out on polar ice sheets (Evans, I967; Evans and others, 1969), and it was of interest to evaluate a similar technique for use on valley glaciers where there are the additional problems of unwanted reflections from the valley sides, and perhaps excessive absorption of the transmitted pulse in the ice, whose condition may vary over a wide range of temperatures, structure and impurity content.

* Full details are published in Report of the Cambridge Staunings Expedition 197o, Vol. 1, obtainable from the libraries of the University of Cambridge Engineering Department or the Scott Polar Research Institute, Cambridge, England. 


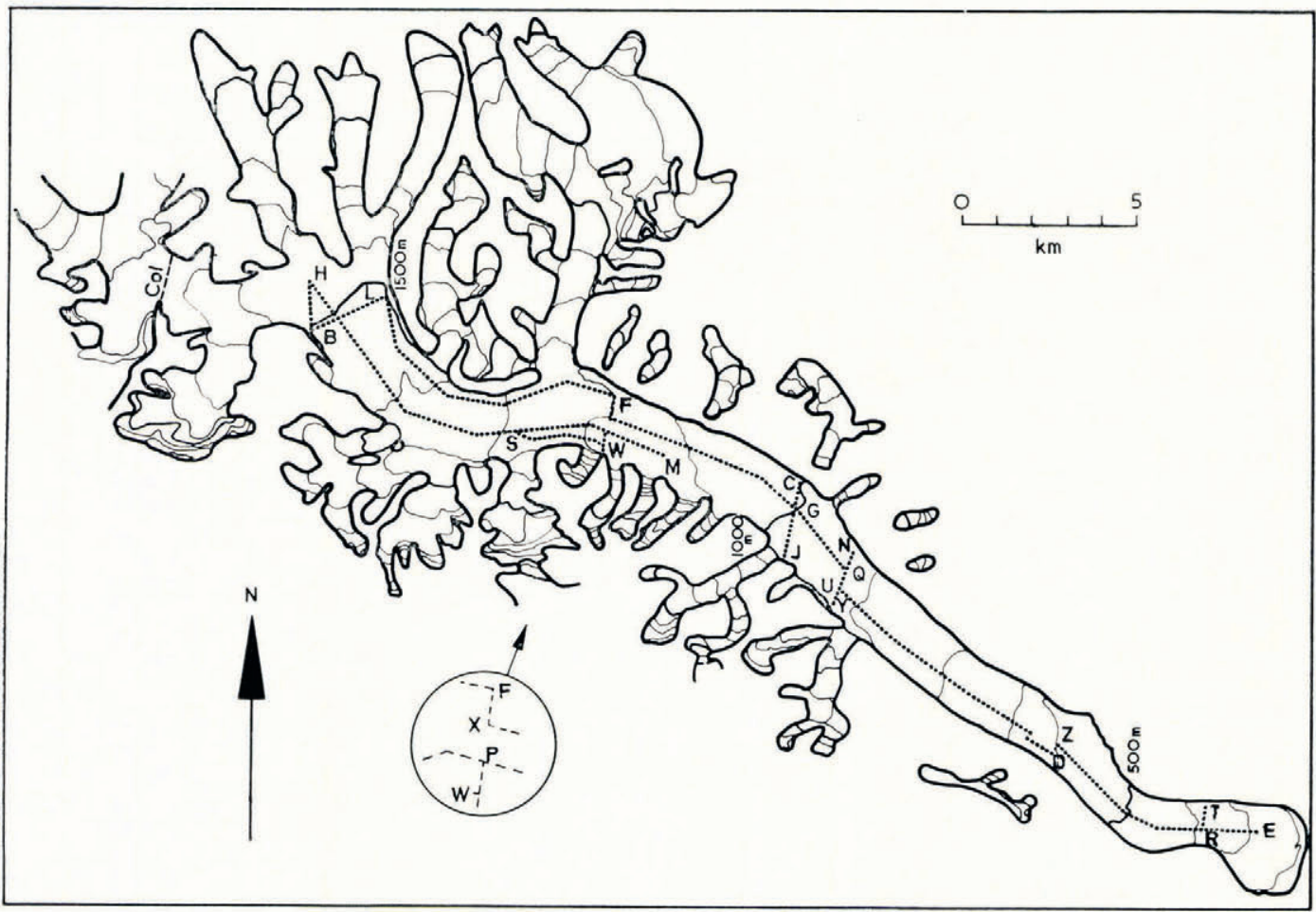

Fig. I. Roslin Gletscher. Radio echo sounding routes.

\section{INSTRUMENTATION AND MEASUREMENT TEGHNIQUE}

It was originally intended to compare the performance of two sounding instruments operating at $\mathrm{I} 5 \mathrm{O}$ and $440 \mathrm{MHz}$. The $\mathrm{I} 5 \mathrm{O} \mathrm{MHz}$ instrument was similar to the $35 \mathrm{MHz}$ model used by the Scott Polar Research Institute in Antarctica (Evans and Smith, I969). However, an unfortunate electrical fault prevented it from being used, and so all work was done at $44^{\circ} \mathrm{MHz}$ using a modified SCR 7 I 8 radio altimeter. The range and accuracy of the SCR 7 I 8 have been discussed by Weber and Andrieux (1970). The internal power supply was altered so that it could be operated from $230 \mathrm{~V}$ a.c. A camera with a continuously moving film was
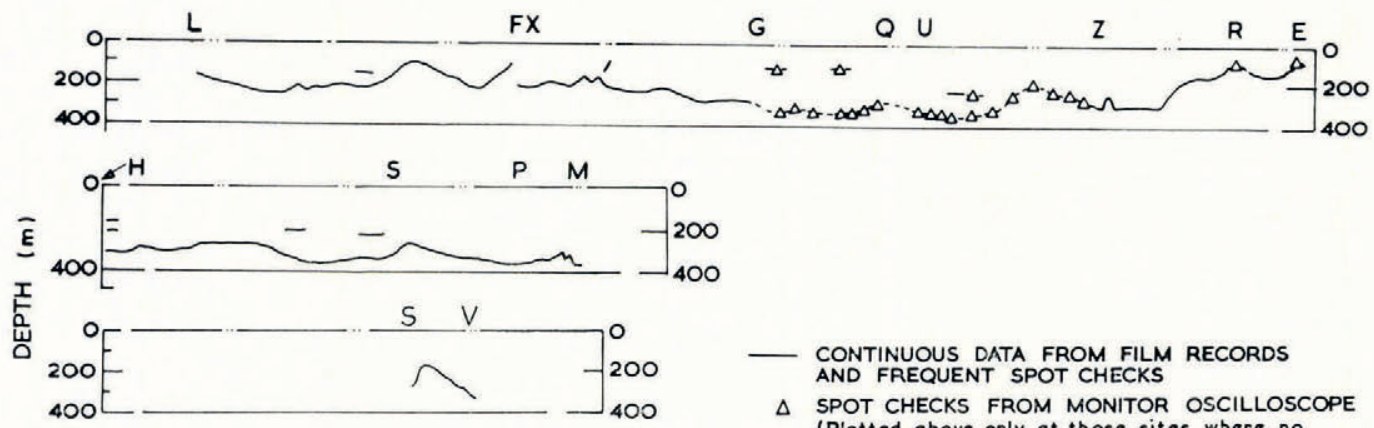

CONTINUOUS DATA FROM FILM RECORDS AND FREQUENT SPOT CHECKS

$\triangle$ SPOT CHECKS FROM MONITOR OSCILLOSCOPE (Plotted above only at those sites where no
film record exists)

Fig. 2. Longitudinal profiles of Roslin Gletscher. Vertical : horizontal scale ratio $\approx 5: I$. 
used to record the intensity-modulated signals on an oscilloscope. It is only by continuously moving over the ice and at the same time continuously recording the echoes that bottom can be seen with certainty amongst scatter echoes. All the equipment was mounted on a sledge and man-hauled over the glacier surface. Two antennae of the rectangular "trough" type, I.5 wavelengths wide by I wavelength long and with corner angles of $45^{\circ}$ were used. The measured forward gain of each antenna was $8 \mathrm{~dB}$.

To correlate echo strength with predicted absorption, ice temperatures were measured at a depth of $9 \mathrm{~m}$, along the length of the glacier.

Several longitudinal and transverse ice-thickness profiles were obtained by radio echo sounding (Figs. 2 and 3 ). Vertical scale calibration marks were put on the recording film at regular intervals using a $500 \mathrm{kHz}$ crystal-controlled oscillator (Fig. 4), and the corresponding locations on the glacier were determined by interpolation using an altimeter and odometer between points fixed by triangulation.
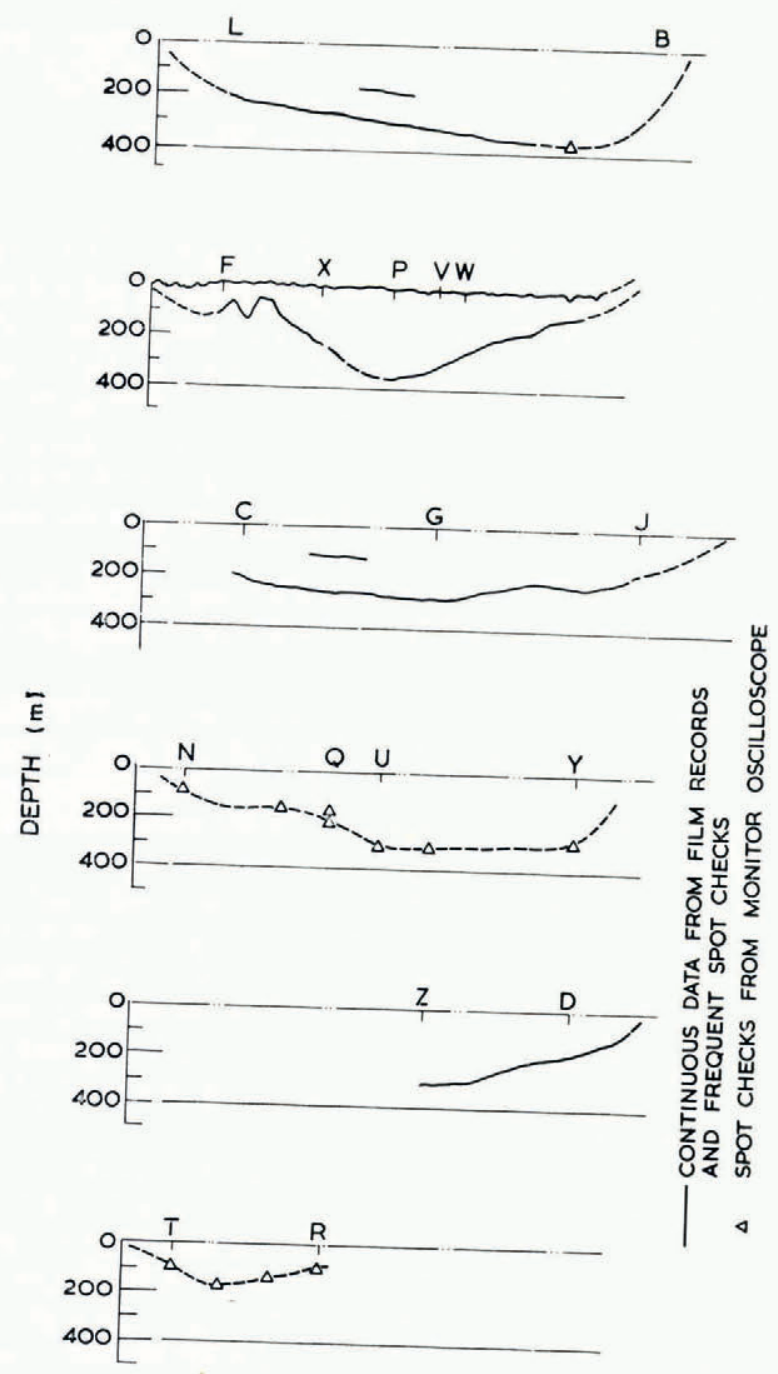

Fig. 3. Transverse profiles of Roslin Gletscher, looking down-stream. Vertical : horizontal scale ratio $I: I$. 


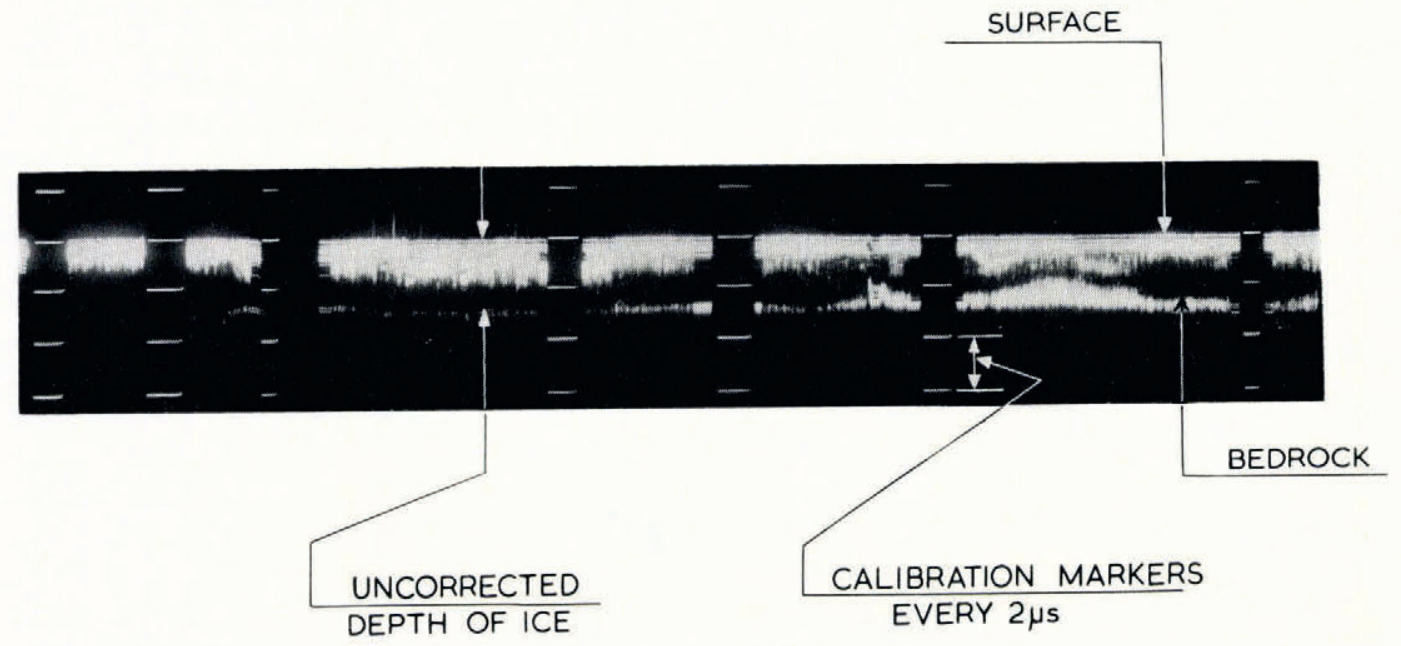

Fig. 4. A film record of ice depths.

\section{Results}

Roslin Gletscher is $37 \mathrm{~km}$ long and has an average width of $2 \mathrm{~km}$. The sledge routes are shown in Figure I. One longitudinal profile of all but the upper $5 \mathrm{~km}$ was completed, as well as six transverse sections and several other profiles. A maximum ice thickness of $370 \mathrm{~m}$ was measured between $\mathrm{B}$ and $\mathrm{L}$, and in many places the ice is about $350 \mathrm{~m}$ thick (Figs. 2 and 3 ).

Reflections from the valley walls were not believed to be present, except when the instrument was being operated within $50 \mathrm{~m}$ of the glacier sides. Thus, using directional antennae on the glacier surface is a satisfactory method of measuring the depth of valley glaciers. Reflections from valley walls are likely to be more serious problems if the equipment is operated from an aircraft due to the larger field of view.

Absorption was higher than that normally found on polar glaciers at similar temperatures. Attenuation per roo $\mathrm{m}$ path length was determined by comparing the received echo traces with traces at known attenuations in the laboratory.

Several mechanisms have been examined to try to account for the high attenuation values from Roslin Gletscher. One possible cause is the presence of water, causing power to be scattered from the forward wave by changes in permitivity. Water may be present either as a surface or englacial layer, or at grain boundaries. Alternatively, the impurity content of the ice may increase the dielectric absorption.

Echo strengths were ro dB stronger at night than during the daytime when melt water was visible on the surface of the glacier. It has been shown that at $440 \mathrm{MHz}$ a layer of water $5 \mathrm{~mm}$ thick accounts for a $10 \mathrm{~dB}$ attenuation to the two-way path. The maximum attenuation for each water layer, I $9 \mathrm{~mm}$ or more thick at $44 \mathrm{o} \mathrm{MHz}$, is I I $\mathrm{dB}$ one way but there may be several layers in the line of sight, each contributing about $5 \mathrm{~dB}$, on average, to the total oneway loss (Smith and Evans, 1972). These attenuations are almost independent of the purity and conductivity of the water.

At zones in which the absorption was determined, the ice temperature at $9 \mathrm{~m}$ depth varied between $-6^{\circ}$ and $-\mathrm{II}^{\circ} \mathrm{C}$. If areas where there was appreciable surface water or reflections from within the ice are neglected, and if only echoes from the ice-bedrock interface are considered, then absorption values varied between 5 and $10 \mathrm{~dB}$ per $100 \mathrm{~m}$ path length, with a mean value of $6.8 \mathrm{~dB}$ per $100 \mathrm{~m}$ path length. These values are higher than those found in polar ice sheets where the absorption is found to be $5.7 \mathrm{~dB}$ per $100 \mathrm{~m}$ at $-\mathrm{I}^{\circ} \mathrm{C}$ and $2.7 \mathrm{~dB}$ per roo $\mathrm{m}$ at $-10^{\circ} \mathrm{C}$ (Robin and others, 1969). 
The range of the SCR 7 8 was found to be satisfactory for measuring the depth of most of Roslin Gletscher. Several interesting physical features emerged from the results. The transverse profile FXPw (Figs. I and 3), below the confluence of the main glacier and a large tributary glacier, indicates that there is a well-defined subglacial ridge which separates the two ice streams, and suggests they maintain their own identity farther down the valley. There is also some evidence to suggest that between B and L, and near $\mathrm{H}$ (Figs. 2 and 3 ), discontinuities (possibly due to the presence of rocks) may be present within the ice at a depth of $200 \mathrm{~m}$. These may have resulted from past avalanche activity on the mountain west of $\mathrm{H}$ (Fig. I). It is a pity that the extent of this feature cannot be determined because of insufficient data.

\section{Conclusions}

The SCR 7 I 8 radio altimeter operating at a frequency of $440 \mathrm{MHz}$ has been shown to give satisfactory ice-thickness measurements on a valley glacier. An advantage of using the fairly high frequency of $44 \mathrm{o} \mathrm{MHz}$ is that antennae are compact and have good forward gain characteristics. Equipment can also be light and compact, and this is often important on a valley glacier where surface travel can be very difficult. Absorption and scattering considerations indicate that a lower frequency might be necessary for good results on some glaciers.

\section{Agknowledgements}

The members of the Cambridge Staunings Expedition 1970 thank all those who helped the radio echo sounding project and especially Dr S. Evans, Scott Polar Research Institute, for his continued assistance and encouragement.

\section{MS. received 23 September I97I}

\section{REFERENCES}

Evans, S. 1967. Progress report on radio echo sounding. Polar Record, Vol. 13, No. 85, p. 413-20.

Evans, S., and Smith, B. M. E. 1969. A radio echo equipment for depth sounding in polar ice sheets. Fournal of Scientific Instruments (Journal of Physics, E), Ser. 2, Vol. 2, No. 2, p. 131-36.

Evans, S., and others. 1969. Glacier sounding in the polar regions: a symposium, [by 5 authors]. Geographical Journal, Vol. 135, Pt. 4, p. 547-63.

Robin, G. de Q., and others. 1969 . Interpretation of radio echo sounding in polar ice sheets, by G. de Q. Robin, S. Evans and J. T. Bailey. Philosophical Transactions of the Royal Society, Vol. 265A, No. 1 166, p. 437-505.

Smith, B. M. E., and Evans, S. 1972. Radio echo sounding: absorption and scattering by water inclusion and ice lenses. Fournal of Glaciology, Vol. I I, No. 61, p. 133-46.

Weber, J. R., and Andrieux, P. 1970. Radar soundings on the Penny Ice Cap, Baffin Island. Journal of Glaciology, Vol. 9 , No. 55 , p. $49-54$. 